ISSN (Online) 2710-3315

https://doi.org/10.20535/EHS.2021.232939

УДК 622.793.5;669.2

\title{
РЕАГЕНТНЕ ОЧИЩЕННЯ ВОДИ ВІД СУЛЬФАТІВ ПРИ ВИКОРИСТАННІ ЧЕРВОНОГО ШЛАМУ
}

\author{
Я.П. Крижановська, М.Д. Гомеля, Т.О. Шаблій \\ Національний технічний університет України \\ «Київький політехнічний інститут ім. Ігоря Сікорського» \\ пр. Перемоги, 37, Київ, 03056, Україна \\ e-mail: yanamart93@ukr.net
}

Сьогодні в Україні, так і в цілому світі, гостро стоїть проблема захисту природних водойм від забруднення. Особливо, якщо йдеться про забруднення високомінералізованими шахтними водами, котрі ніяким чином не підлягають утилізації, а попросту скидаються у природні водойми без попереднього очищення.

Також, слід зазначити, що питання стоїть не лише в процесі очистки природних водойм, а саме в економічно вигідному та раціональному процесі очистки. Якщо мова йде про реагентне очищення вод, яке передбачає використання дороговартісних алюмінієвих коагулянтів, то питання постає у реалізації відходів з алюмінієвого виробництва, а саме - червоного шламу. Якщо враховувати, що існує необхідність знесолення елюатів і концентратів з високим вмістом сульфатів - то використання червоного шламу замість дорогих коагулянтів гідроксохлоридів алюмінію та алюмінату натрію, стає мега актуальним та економічно вигідним, а також раціональним. А саме, використання відходів з глиноземного заводу червоного шламу, $\epsilon$ економічно вигідним та перспективним напрямком розвитку безвідходного виробництва.

Метою даної роботи є вивчення складу червоного шламу з перспективою використання при очистці вод від сульфатів, а також визначити залежність ефективності видалення 3 води сульфатів від витрати вапна і червоного шламу.

Науковою новизною роботи є видалення сульфат аніонів реагентним методом у вигляді нерозчинних осадів, на відміну від інших методів, таких як баромембранні, іонний обмін, електродіаліз, в результаті проведення яких утворюються рідкі елюати та концентрати, котрі потребують складної та дороговартісної утилізації. Нерозчинний осад, що утворюється в результаті реагентного видалення, можливо реалізовувати у будівельній галузі, тому що він не являється токсичним і є цілком безпечним.

В роботі використовувались модельні розчини сульфату магнію концентрацією 18,3 та 38,5 мг-екв/дм³ . Вищі концентрації використовувати було недоцільно, тому що при обміні сполуками кальцію концентрацію гіпсу можна знизити до 31 мг-екв/дм ${ }^{3}$ тому що дана концентрація $\epsilon$ межею його розчинності. Як шлам, використовували відходи Миколаївського глиноземного заводу (МГЗ), що утворились при виробництві глинозему $\left(\mathrm{Al}_{2} \mathrm{O}_{3}\right)$ методом Байєра [1]. 3 часів розроблення Байєровського процесу, червоний шлам накопичено у величезній кількості близько алюмінієвих комбінатів, розташованих у багатьох країнах світу. На кожну тонну отриманого глинозему припадає від 300 до 2000 кг шламу. 
Задовільних методів його утилізації, зважаючи на величезну кількість відходів, не знайдено. Тому використання шламу в очисній галузі є мега актуальним та вигідним.

При проведенні експериментальних досліджень у розчин сульфату магнію об'ємом 200 см $^{3}$ додавали шлам у кількості від 1 до 50 г/дм³

Після цього при поступовому перемішуванні додавали суспензію вапна у воді. Суспензію відстоювали протягом 2,5 годин та фільтрували на фільтрі «синя стрічка». У пробах очищеної води визначили залишковий вміст сульфатів та $\mathrm{pH}$ середовища. Відомо, що сульфати у більшості випадків, висаджуються із води у вигляді гідроксосульфаталюмінату кальцію, загального складу $3 \mathrm{CaO} \bullet \mathrm{Al}_{2} \mathrm{O}_{3} \cdot 3 \mathrm{CaSO}_{4} \cdot 31 \mathrm{H}_{2} \mathrm{O}[1]$.

Червоний шлам в основному складається із сполук заліза, що присутні у вигляді оксидів та гідроксидів, кристали яких включають іони алюмінію. Даний шлам практично нерозчинний у воді і при змішуванні з водою утворює стійкі суспензї яскраво помаранчевого кольору при підвищенні рН води до 9,0-10.

Слід відмітити, що при додаванні у розчини сульфату магнію просто шламу без обробки отриманих суспензій вапном відділення осаду від розчину фільтруванням неможливе у використанні паперового фільтру «синя стрічка» або мікрофільтраційних мембран. Суспензія настільки дрібнодисперсна, що фільтрувальні матеріали просто забиваються і втрачають здатність пропускати воду.

При обробці суспензій вапном відбувається укрупнення або коагуляція завислих часток. Також слід відмітити, при додаванні вапна створюються умови для формування осаду сульфоалюмінату кальцію, що сприяє сорбції сульфатів із розчину та укрупненню часток суспензії [2]. Очевидно, що у присутності вапна та сульфатів у розчині, вони можуть взаємодіяти із частками оксиду алюмінію, котрий присутній у шламі 3 утворенням малорозчинного гідроксоалюмінат натрію [3, 4]. При цьому, ефективність зв'язування сульфатів залежить від співвідношення кількості шламу та вапна у водному середовищі. Це добре видно із рис.1.

Так, при витраті шламу всього 1 г/дм³ мінімальної концентрації сульфатів вдалось досягти при витраті вапна 3 мг-екв/дм³ . При дозі шламу 5 г/дм³ мінімальної концентрації вапна вдалось досягти при витраті вапна 12 мг-екв/дм³. Найкращим результатом було зниження концентрації сульфатів до концентрації 236 мг-екв/дм³ при витраті шламу 10 г/дм³ та вапна - 12 мг-екв/дм³. Подальше збільшення витрати шламу не сприяла підвищенню ефективності вилучення сульфатів із води. При витраті шламу 20 г/дм³ мінімальна концентрація сульфатів була на рівні 330 мг-екв/дм³ , а при витраті шламу 50 г/дм³ концентрацію сульфатів вдалось знизити лише до 368 мг-екв/дм³ при максимальній витраті вапна.

3 іншої сторони при використанні розчину сульфату магнію концентрацією 38,54 мгекв/дм ${ }^{3}$ не було відмічено значного підвищення сорбційною ємності шламу по сульфатах (рис. 2). 
Матеріали XXII Міжнародної науково-практичної конференції «Екологія. Людина. Суспільство» (м. Київ, Україна, 2021 р.)

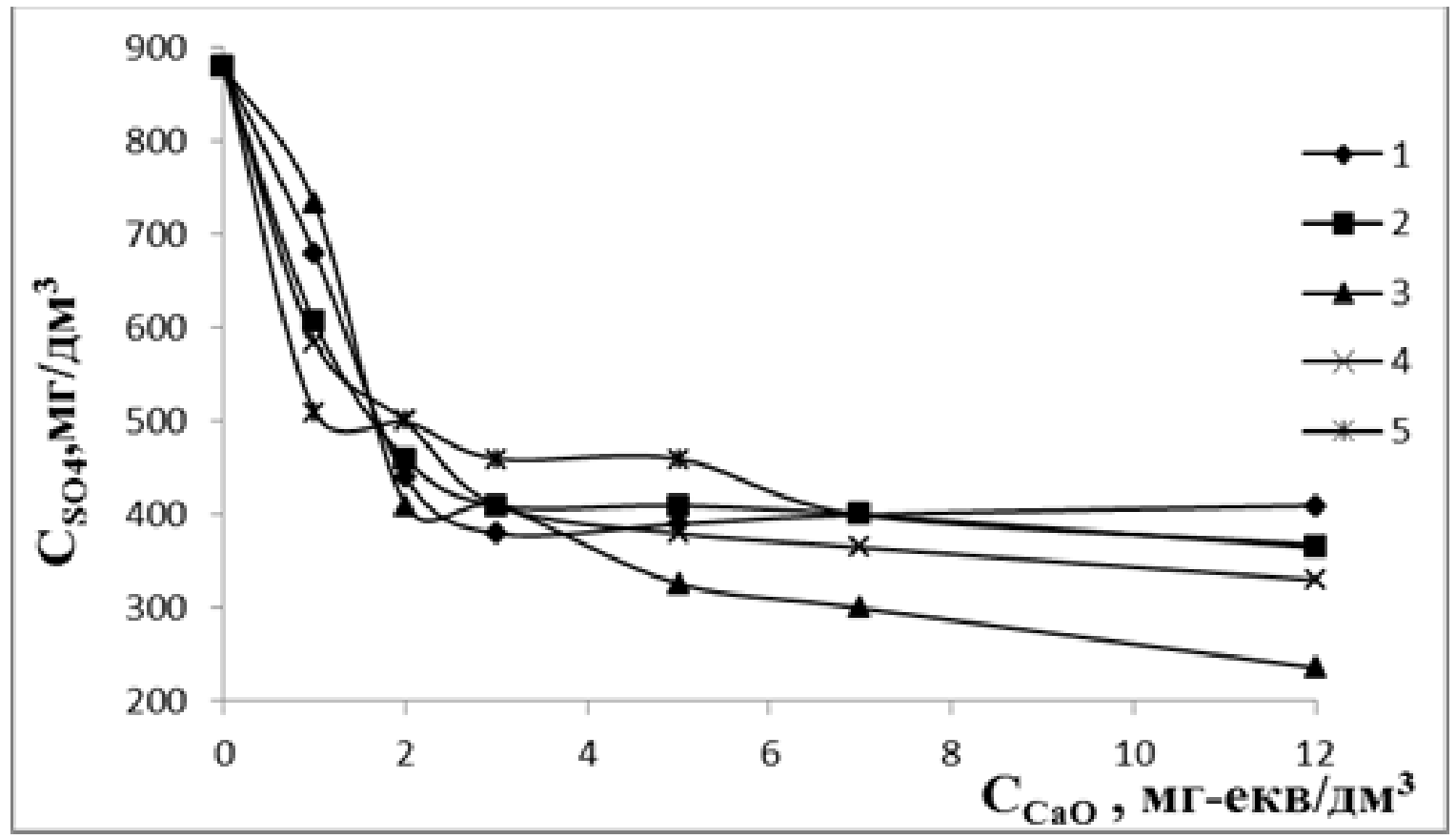

Рисунок 1. Залежність залишкової концентрації сульфатів у розчині сульфату магнію $\left(\mathrm{CMgSO}_{4}=18,3\right.$ мг-екв/дм $\left.{ }^{3}\right)$ від витрати вапна при витраті шламу г/дм³ : 1 (1); 5 (2); $10(3) ; 20(4) ; 50(5)$



Рисунок 2. Зміна залишкової концентрації сульфатів у розчині сульфату магнію $\left(\mathrm{CSO}_{4}=1850\right.$ мг/дм $\left.{ }^{3}\right)$ в залежності від витрати вапна при витраті шламу, г/дм ${ }^{3}: 1$ (1), $5(2), 10(3), 20(4), 50(5)$ 
При цьому найбільше зниження сульфатів відмічено при витраті шламу всього 1 г/дм³ при дозі вапна 30 мг-екв/дм³. Подальше підвищення витрати шламу та витрати вапна не сприяло підвищенню ефективності вилучення сульфатів. Мінімальні концентрації сульфатів при витраті вапна 30 мг/дм ${ }^{3}$ сягали 550-830 мг/дм³ , при всіх витратах шламу.

В цілому, можемо зробити перші висновки про те, що процес вилучення сульфатів в значній мірі залежить від співвідношення концентрацій сульфатів, вапна і шламу. Це, очевидно, впливає на процес зв'язування сульфатів на поверхні шламу з утворенням сульфоалюмінату кальцію.

Можна припустити, що при відносно невисоких витратах шламу при достатній концентрації вапна відбувається їх зв'язування із вапном та сульфатами у нерозчинні сполуки, котрі з легкістю можна фільтрувати. При збільшенні витрати шламу на порядок і більше при використаних дозах вапна лужність недостатня для вилуговування сполук алюмінію із поверхні, що супроводжується зв'язування сульфатів на поверхні часток шламу.

В результаті проведених досліджень по використанню червоного шламу, що утворюється при виробництві на Миколаївському глиноземному заводі було визначено, що при використанні шламу в кількості 1-50 г/дм³ при обробці розчинів сульфату магнію при вапнуванні води відбувається очищення води від сульфатів. При цьому ступінь очищення досягає 50-70\%. Це є досить позитивним результатом, із врахуванням того, що очищення відбувається за мінімальних витрат, при використанні відходів певного виробництва. Можна припустити, що даний метод очищення вод від сульфатів, можна використовувати як перший етап очистки води. Було встановлено, що ефективність вилучення сульфатів суттєво залежність від витрати вапна і мало зростає при збільшенні витрати шламу понад 1 г/дм².

\section{Література:}

1. Гомеля М.Д., Крижановська Я.П., Шаблій Т.О. Оцінка ефективності використання червоного шламу при очищенні води від сульфатів // Вісник Національного технічного університету України «Київський політехнічний інститут імені Ігоря Сікорського». Серія «Хімічна інженерія, екологія та ресурсозбереження». 2021. № 1 (20). С. 55-62.

2. Gomelya M., Hrabitchenko V., Trokhymenko A., Shabliy T., Reaserch into ion exchange softening of highly mineralized water // Eastern-Europen journal of Enterprise Technological, 2016. 4/10 (82). P. 4-9.

3. Epsztein R., Nir O., Lahav O., Green M., Selective nitrate removal from groundwater using a hybrid nanofiltration-reserse osmosis filtration scheme // Chemical Engineerihg Journal, 2015. 279. P. 372-378.

4. Gomelya M., Trokhymenko A., Hlushko O., Shabliy T. Electroexstration of heavy metal from wastewater for the protection of natural water bodies pollution // Eastern-Europen journal of Enterprise Technological, 2018. 1/10 (91). P. 55-61. 